\title{
PRE-DIABETES DAN PERAN HBA1C DALAM SKRINING DAN DIAGNOSIS AWAL DIABETES MELITUS
}

\author{
Meddy Setiawan*
}

\begin{abstract}
Abstrak
Diabetes Mellitus (DM), khususnya DM tipe 2 (DMT2) kini menjadi ancaman yang serius bagi umat manusia di dunia. Riset Kesebatan Dasar (RISKE:SDAS) yang dilaporkan oleh Departemen Kesehatan pada tahun 2008, menunjukean prevalensi DM di ludonesia saat ini sebesar 5,7\%. Menurut WHO pasien diabetes di Indonesia akan mengalami kenaikan dari 8,4 juta jina pada tabun 2000 dan menjadi sekitar 21,3 juta jüva pada tabun 2030. Tanpa upaja pencegaban dan program pengendalian yang efektif prevalensi tersebut akan terus meningleat.

Glukasa darah merupakan rentang yang berkelanjulan (continuous spectrum). Batas kadar gluk,nsa darab normal, prediabetes dan diabetes ditetapkan berdasar kesepakatan (arbitrary). Saat ini, diagnosis DM ditetapkan bila kadar glukesa darab puasa $>126 \mathrm{mg} / \mathrm{dl}$ atau 2 jam paska beban glukosa $>200 \mathrm{mg} /$ dl. Prediabetes adalah kadar glukosa darab di atas normal tetapi masib di bawab kadar glukasa darab untuk diabetes. Diagnosis prediabetes ditegakean bila didapatkan kadar glukasa darah puasa 100-125 mg/dl (Glukosa Puasa Terganggu $=$ GPT), atau 2 jam paska beban glukesa $140.199 \mathrm{mg} / \mathrm{dl}$ (Toleransi Glukosa Terganggu = TGT), atau keduanyat (Homeostasis Glukosa Terganggu $=$ HGT).

Mekanisme patofisiologi TGT dan GPT berbeda, meskipun TGT dan GPT didasari oleb resistensi insulin, tetapi kediuanya menunjukkan perbedaan tempat dimana resistensi insulin terjadi. Resistensi insulin pada penderita GPT terutama pada jaringan bati, sedangkan sensitifitas insulin pada jaringan otot masib tetap normal. Pada TGT, sensitifitas insulin di jaringan bati tetap normal alau sedikit menurun sedangkan pada jaringan otot telab terjadi resistẹnsi insulin.

Prediabetes meningkatkan resiko absolut menjadi DM sebesar 2-10 kali lipat, resiko terjadinya penyakil kardiovaskular pada prediabetes sama besarnya dengan DM. Berbagai keadaan tersebut lebib meyakinkan babwa Tindakan-findakan dan program pencegaban dini DM sangat diperlukan, antara lain melalui penanganan prediabetes. Identifikasi dan penatalaksanaan anal bagi pasien prediabetes dapat methurunkan insiden DM serta komplikasinya.

Diabetes merupakan salab satw penyakit underdiagnosed. Saat diagnosis ditegakkan sekitar $25 \%$ sudab terjadi kamplikasi mikrovaskular. Manfaat HbAlc selama ini lebils banyak dikenal dalam menilai kualitas pengendalian glikemik jangka panjang dan menilai efektinitas suatu lerapi, namun beberapa studi terbaru mendukung manfaat HbAlc yang semakin luas, bukan banya untuk pemantauan, tetapi juga bermanfaat dalam mendiagnosis ataupun skining Diabetes Mellitus tipe-2.

Pasien DM berpotensi menderita berbagai komplikasi, meliputi penyakit makerovaskular (pentyakit jantung, stroke dan penyakit pembulub darab tepi) dan penyakit mikrotaskular (retinopati, neuropati dan nefropati). Komplikasi DM sudab dimulai sejak dini sebelum diagnosis DM difegakkan.
\end{abstract}

Kata kunci : prediabetes, $H \mathrm{~b} A 1$, , DM tipe 2

\footnotetext{
* Slaff Pengajar Pada Fakultas Kedokteran

Universitas Mutbammadiyab Malang
} 


\section{Abstrak}

Diabetes Mellitus (DM), especially type 2 DM is now beconing serious threat for manking in all over the world. Riset Kesebatan Dasar (RISKESSAS Basic Health Research) reported in 2008, showed that DM prevalence in Indonesis at that moment wa.5 5,7\%. WHO states that there will be an increasing in diabetes patient in Indonesia from 8,4 millions in 2000 to be approximately 21,3 millisns in 2030 . Withoul any effective prevention and controlling programs, that prevalence will undoubtfully keep going up.

Blood glucose is a continuous spectrum. Normal blood glucose limit, prediabetes and diabetes are set based on arbitrary. Currently, DM diagnasis is established when fasting blood glucose level $>126 \mathrm{mg} / \mathrm{dL}$ or 2 bour post glucose burden $>200 \mathrm{mg} / \mathrm{dL}$. Prediabeles is blood ghicose level above normal but still belowblood glucose level for diabetes. Prediabetes diagnosis is eslablished if the level of fasting blood glucose is 100-125 mg/dl (Impaired Fasting Glucose $=I F G$ ), or 2 bour post glucose burden 140-199 mg/dL, (Impaired Glucose Tolerance $=I G T$ ), or bolb (Impaind Glucose Homeostasis = IGH)

Patsophysiology mechanisms of IGT and IFG are different, eventhough IGT and IFG are both caused by insulin resistences, and bowever; both show different site where insulin resistences take place. Insulin resistences in IFG patient is primarily in liver tissue, while insulin sensitivity in muscle tissue remains normal. In IGT, insulin sensitivity in liver tissue remains normal or a little decrease while there bas been insulin resistence in muscle tissue.

Prediabetes increases absolute risk to be DM 2-10 times bigher, the risk of cardionascular disease in prediabetes is as big as with DM. Those various conditions convince more that actions and DM early prevention progran is absolutely required, for example by prediabotes management. Identification and early management for prediabetes patient which are able to reduce DM incidence and the complication.

Diabetes is one of underdiagnosed diseases. The diagnosis is already established, about $25 \%$ there is also already microvascular complication. The use of $\mathrm{HbA1}$, is these times mostly knonn for evaluating long term glycemic continl quality and certuin lberapy effectiveness, bowever, some most recent studies support the wider use of $H b A 1$, not only for monitoring, but also useful in diagnosing and screening of type-2 Diabetes Mellitus as well.

DM patient potentially suffers from various complications, including microvascular diseases 9beart disease, stroke and peripheral vascular disease). DM complication starts early before DM diagnosis is establisbed.

Keywords : prediabetes, HbA1c, type 2 DM

\section{Diagnosis Prediabetes}

Diagnosis prediabetes (GPT dan atau TGT) ditegakkan sesuai dengan rekomendais WHO. Diagnosis GPT ditegakkan bila kadar glukosa darah setelah puasa sekitar 8-10 jam adalah $100-125 \mathrm{mg} /$ dl (5,6-6,9 mmol/L). Diagnosis TGT ditegakkan bila kadar glukosa darah 2 jam paska beban glukosa $75 \mathrm{gram}$, diantara $140-199 \mathrm{mg} / \mathrm{dl} \quad(7,8-11 \mathrm{mmol} /$ L).

Berbagai studi epidemiologis belum semuanya menggunakan glukosa darah 2 jam paska beban untuk menegakkan diagnosis prediabetes dan hanya meenggunakan hasil glukosa darah puasa. Hal ini dapat menimbulkan hasil negatif palsu, mengingat TGT tidak akan terdeteksi. Individu dengan kadar glukosa darah puasa normal mungkin termasuk dalam TGT bila dilakukan TTGO. Deteksi adanya TGT perlu dilakukan mengingat kecenderungan menjadi DMT2 dan resiko terjadinya komplikasi kardiovaskular lebih tinggi pada subjek dengan TGT dibanding pada individu dengan GPT.

Beberapa faktor resiko penyakit kardiovaskular dan diabetes sering dijumpai dalam satu individu. Berbagai faktor resiko tersebut adalah : obesitas, hipertensi, kadar kolesterol bight density lipoprotein (HDL) yang rendah, kadar triglisetida yang meningkat, dan gangguan metabolisme glukosa, yang dikenal sebagai sindroma metabolik. Sindrom metabolik dianggap setara dengan prediabetes. (Soeatmadji W Djoko dkk, 2009)

\section{Faktor Risiko Prediabetes}

Faktor risiko terjadinya prediabetes sama dengan faktor risiko DM tipe 2. Faktor resiko tersebut dapat dibagi menjadi faktor risiko yang dapat dirubah (obesitas, aktivitas fisik, nutrisi) dan yang tidak dapat dirubah (genetik, usia, diabetes gestasional). Faktor yang dapat dirubah, yang penting adalah obesitas (terutama perut) dan kurangnya aktifitas fisik. (Soealmadji W Djoko dkk, 2009; Harrison T.R, 2008; Alberti K G M, ZImmet $P$ and Shaw J. 2007)

\section{a. Faktor genetik}

Gen yang berhubungan dengan resiko terjadinya DM, sampai saat ini belum bisa diidentifikasi secara pasti. Adanya perbedaan yang 
nyata kejadian DM antara grup etnik yang berbeda meskipun hidup di lingkungan yang sama menunjukkan adanya kontribusi gen yang bermakna dalam terjadinya DM.

\section{b. Usia}

Prevalensi DM meningkat sesuai dengan pertambahnya usia. Dalam dekade terakhir ini, usia terjadinya DM semakin muda..

\section{c. Diabetes gestasional}

Pada diabetes gestasional, toleransi glukosa biasanya kembali normal setelah melahirkan akan tetapi wanita tersebut memiliki resiko untuk menderita DM di kemudian hari.

\section{d. Obesitas}

Obesitas merupakan faktor resiko yang paling penting. Beberapa studi jangka panjang menunjukkan bahwa obesitas merupakan prediktor yang kuat untuk timbulnya DM tipe 2. Lebih lanjut, intervensi yang bertujuan mengurangi obesitas juga mengurangi insidensi DM tipe 2. Beberapa studi jangka panjang juga menunjukkan bahwa ukuran lingkar pinggang atau rasio pinggang-pinggul (waist to bip ration) yang mencerminkan keadaan lemak visceral (abdominal), merupakan indikator yang lebih baik dibandingkan indeks masa tubuh sebagai faktor resiko prediabetes. Data tersebut memastikan bahwa distribusi lemak lebih penting dibanding dengan jumlah total lemak.

\section{e. Aktifitas fisik}

Berkurangnya intensitas aktifitas fisik memberikan konstribasi yang besar terhadap peningkatan obesitas. Berbagai studi menunjukkan bahwa kurangnya aktifitas fisik merupakan predikor bebas terjadinya DM tipe 2 pada pria maupun wanita.

\section{f. Nutrisi}

Kalori total yang tinggi, diit tendah serat, beban glikemik yang tinggi dan rasio poly unsaturated fatty acid (PUFA) dibanding lemak jenuh yang rendah, merupakan faktor tediko terjadinya DM.

\section{Gambaran Gula Darah Pada Diabetes Melitus}

Kadar glukosa darah merupakan rentang yang berkelanjutan (continuous spectrum) diantara kadar glukosa darah yang dianggap normal (puasa $<100 \mathrm{mg} / \mathrm{dl}$; paksa beban $<140 \mathrm{mg} / \mathrm{dl}$ ) dan kadar glukosa darah yang dianggap diagnostik untuk diabetes (puasa $>126 \mathrm{mg} / \mathrm{dl}$; paska beban glukosa $75 \mathrm{gram}>\mathrm{mg} / \mathrm{dl}$ ). Batas kadar glukosa darah tersebut terkait dengan saat timbulnya komplikasi yang khas untuk diabetes (end-organ complication), khususnya retinopati. Dari berbagai studi, ternyata batas kadar glukosa darah puasa dan 2 jam paska beban yang terkait dengan timbulnya komplikasi sesungguhnya lebih rendah dari batas kadar glukosa darah yang saat ini dipakai, mengingat bahwa ketika dasar glukosa darah masih dibawah batas "normal" mungkin sudah terjadi peningkatan risiko komplikasi diabetes mikrovaskuler dan makrovaskulat. (Soeatmadji W Djoko dkk, 2009; Harrison T.R, 2008)

Dalam perjalanan penyakitnya, $6-10 \%$ pasien TGT akan menjadi diabetes dalam waktu 1 tahun. Pasien dengan TGT dan GPT dalam waktu 6 tahun, insiden kumulatif diabetes sebesar $60 \%$, sedangkan pada individu dengan toleransi glukosa yang normal insidensi diabetes hanya sekitar $5 \%$. (Soeatmadji W Djoko dkk, 2009)

\section{HbA1c dan Average Glucose}

HbA1 adalah spesifik hemoglobin terglikasi yang terbentuk akibat adanya penambahan glukosa terhadap asam amino valin $\mathrm{N}$-terminal pada tantai $\hat{a}-$ hemoglobin $[\hat{a}-\mathrm{N}$ (1-deeoxy) fructosyl-Hb]. Konsentrasi hemoglobin terglikasi (HbA1c) ini tergantung pada konsentrasi glukosa darah dan masa hidup erittosit. HbA1c biasanya dinyatakan sebagai persentase dari total hemoglobin. Korelasi antara nilai $\mathrm{A} 1 \mathrm{c}$ dengan perkiraan rata-rata glukosa plasma dapat dilihat pada tabel 1 berdasarkan hitungan formula konversi yang merupakan hasil studi multinational ADAG (A1c Derived Average Glucose) yang didukung oleh American Diabetes Association $(\mathrm{ADA})$, European Asscociation for the Study of Diabetes (EASD) dan International Diabetes Federation (IDF) Little RR and Sacks DB. 2009; Gallagher Ej, Roith $D$, Blloomgarden Z., 2009) :

\begin{tabular}{|c|c|}
\hline 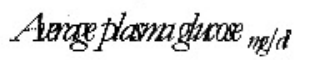 & $=287 \times$ HA1c -467 \\
\hline Aorage plavnaghooe ma/L & $=159 \times \mathrm{HAlc}-259$ \\
\hline
\end{tabular}


60 Vol. 7 No. 14 Januari 2011

Tabel 1. Korelasi A1c dengan Perkiraan Rata-Rata Glukosa Plasma (6)

\begin{tabular}{|c|c|c|}
\hline $\mathrm{A} 1 \mathrm{c}(\%)$ & $\mathrm{eAG}(\mathrm{mg} / \mathrm{dl})$ & $\mathrm{eAG}(\mathrm{mmol} / \mathrm{L})$ \\
\hline 6 & 126 & 7.0 \\
\hline 7 & 154 & 8.6 \\
\hline 8 & 183 & 10.1 \\
\hline 9 & 212 & 11.8 \\
\hline 10 & 240 & 13.4 \\
\hline 11 & 269 & 14.9 \\
\hline 12 & 298 & \\
\hline
\end{tabular}

\section{Rekomendasi International Expert Committee}

International Expert Comnittee menyatakan bahwa individu dengan nilai HbA1c rendah bukan berarti tidak berisiko diabetes, namun lebih tepat disebut berisiko tendah. Individu yang berisiko tinggi menyandang diabetes (termasuk individu yang tinggi kadar trigliserida, tekanan darah, dan BMI-nya atau adanya riwayat keluatga) dianjurkan mengurangi berat badan serta betolahraga secara teratur.

Tabel 2. Rekomendasi International Expert Committee tentang peranan A1c dalam diagnosis dan identifikasi individu risiko tinggi (The Internal Expert Committee, 2009)

- A1c merupakan pemeriksaan yang akurat dan tepat dalam mengukur kadar glikemik kronis serta berkorelasi positif dengan terjadinya risiko komplikasi diabetes

- A1c memiliki beberapa kelebihan dibanding glukosa.

- Diagnosis ditegakkan jika nilai A1c $\geq$ 6,5\%. Diagnosis sebaiknya dikonfirmasi dengan pengulangan pemeriksaan $\mathrm{A1c}$. konfirmasi tidak perlu bagi individu yang menunjukkan gejala dengan kadar glukosa plasma $>200 \mathrm{mg} / \mathrm{dL}(11.1 \mathrm{mmol} / \mathrm{L})$

- Jika $A 1 \mathrm{c}$ tidak memungkinkan untuk dilakukan, maka sebaiknya melakukan metode diagnostik seperti yang direkomendasikan sebelumnya (mis. Pemeriksaan glukosa plasma puasa, atau glukosa plasma 2 jam, dengan konfirmasi)

- Pemeriksaan A1c dapat diindikasikan pada anak suspect diabetes namun tidak didapati adanya gejala klasik dan memiliki kadar plasma glukosa tidak melebihi 200 $\mathrm{mg} / \mathrm{dL}(>11.1 \mathrm{mmol} / \mathrm{L})$
- Risiko diabetes berdasarkan kadar glikemik merupakan suatu rangkaian kesatuan, di mana tidak didapati adanya ambang batas glikemik yang rendah pada awal risiko.

- Jika kategori klinis keadaan pre-diabetes. IFG (inpaired fosting glucose) dan IGT (impaired ghucose tolerance) tidak merupakan suatu rangkaian kesatuan risiko maka pengukuran A1c dapat menggantikan pengukuran glukosa.

- Seperti halnya untuk diagnosis diabetes. Pemeriksaan A1c juga memiliki bebetapa kelebihan dibanding glukosa dalam mengidentifikasi individu yang berisiko tinggi.

- Kadar A1c-6,4\% diduga lebih berisiko berkembang menjadi diabetes, tergantung pada faktor risiko diabetes lainnya. Oleh sebab itu lebih baik melakukan usaha pencegahan. 


\section{Kelebihan dan keterbatasan HbA1c}

Beberapa faktor yang menjadi alasan utama yang mendukung penggunaan $\mathrm{HbA1c}$ sebagai alat untuk skrining dan diagnosis diabetes (Little $R R$ and Sacks DB. 2009; The Internal Expert Comnittee., 2009; Saudek CD, Herman WH, Sacks DB, Bergenstal RM, Edelman D, Davidson MB., 2008) :

- Tidak perlu puasa dan dapat diperiksa kapan saja.

- Dapat memperkirakan keadaan glukosa darah dalam waktu yang lebih lama serta tidak dipengaruhi oleh perubahan gaya hidup jangka pendek.

- Variabilitas biologisnya dan instabilitas preanalitiknya lebih rendah dibanding glukosa plasma puasa.

- Kesalahan yang disebabkan oleh faktor nonglikemik yang dapat mempengaruhi nilai HbA1c sangat jarang ditemulkan dan dapat diminimalisasi dengan melakukan pemeriksaan konfirmasi diagnosis dengan glukosa plasma.

- Relatif tidak dipengaruhi oleh gangguan akut (mis. stres atau penyakit yang terkait).

- Lebih stabil dalam suhu kamar dibanding glukosa plasma puasa.

- Lebih dirckomendasikan untuk monitoring pengendalian glukosa.

- Level HbA1c sangat betkorelasi dengan komplikasi diabetes.

Sebaliknya, HbA1c sebagai alat untuk skrining atau diagnosis juga memiliki beberapa keterbatasan, antara lain (Little RR and Sacks DB. 2009; The Internal Expert Committee., 2009, Saudek CD, Herman WH, Sacks DB, Bergenstal RM, Edelman D, Davidson MB., 2008) :

1. Keadaan Hemoglobin trait seperti $\mathrm{HbC}$, $\mathrm{HbF}, \mathrm{HbE}$ dan $\mathrm{HbS}$ dapat mengganggu pemeriksaan $\mathrm{HbAlc}$. akan tetapi sekarang banyak metode yang telah dapat menanggulangi masalah bemoglobin trait ini.

2. Keadaan yang dapat mempengaruhi red cell thrnover seperti anemia hemolitik malaria kronis, major blood loss atau tranfusi darah dapat mengganggu nilai HbA1c. Anemia hemolitik dapat menyebabkan hasil rendah palsu karena hemoglobin pada sel darah muda lebih sedikit mendapat gula dari lingkungan sekitarnya. Pendarahan aktif menyebabkan peningkatan produksi reikulosit, yang akan mengurangi umur rata-tata eritrosit dan menyebabkan hasil $\mathrm{HbA1c}$ rendah palsu. Sebaliknya, beberapa kondisi yang dapat meningkatkan usia rata-rata eritrosit dan sirkulasi seperti splenektomi (akan memperlambat klitens sel darah merah) ataupun enemia aplastik (keadaan dimana produksi retikulosit terganggu) dapat menyebabkan hasil tinggi palsu yang independen dengan keadaan glikemik.

3. Saat interpretasi HbA1c bermasalah, penggunaan glukosa puasa dan postprandial dianjurkan tetap dapat digunakan,

4. Nilai $\mathrm{I}-\mathrm{Ib} \Lambda 1 \mathrm{c}$ menunjukkan peningkatan seiring bertambahnya usia, akan tetapi besarnya perubahan dan pengaruh usia terhadap peningkatan $\mathrm{Hb} A 1 \mathrm{c}$ belum terlalu jelas untuk mengadopsi age-specific values dalam diagnosis. Begitu pula dicluga adanya peran etnis yang tampaknya mempengaruhi nilai $\mathrm{HbAlc}$, namun hal ini belum jelas schingga dinilai terlalu dini untuk mengeluarkan rate-specific diagnostic value.

\section{Pencegahan Diabetes Mellitus}

Berbagai studi menunjukkan hubungan yang linier antara status glikemia dengan risiko Penyakit Kardio Vaskuler (PKV). Kelompok prediabetes memiliki risiko terjadinya komplikasi seperti diabetes. Dalam kaitan terjadinya resiko diabetes dan PKV pada kelompok prediabetes, ternyata 'T'GT lebih terkait dengan kedua resiko tersebut dibanding dengan GPT. Diperlukan langkah pencegahan yang segera untuk menurunkan jumlah penderita prediabetes, DMT2 dan penyakit kardiovaskular yang terkait diabetes. Langkah-langkah pencegahan meliputi (Soeatmadji $W$ Djoko dk.k, 2009; Harrison T.R, 2008; Alberti K G M, ZImmet P and Shaw J. 2007) :

\section{Intervensi Gaya Hidup}

Modifikasi gaya hidup merupakan bagian utama terapi dan diberikan pada semua pasien dan hatus diingatkan pada setiap kunjungan pasien. Gaya hidup merupakan pendekatan pengelolaan fundamental yang dapat mencegah atau menunda berkembangnya prediabetes menjadi diabetes, serta menurunkan risiko penyakit mikrovaskular dan 
makrovaskular. Intervensi gaya hidup memperbaiki semua faktor risiko diabetes dan komponen sindrom metabolik, obesitas, hipertensi, dislipidemi dan hiperglikemi. Sesuai hasil Diabetes Prevention Program (DPP), pasien prediabetes seharusnya menurunkan berat badan $5-10 \%$ dan mempertahankannya secara berkelanjutan. Penurunan berat badan yang moderat tersebut menghasilkan penurunan masa lemak, tekanan darah, glukosa, kolesterol low density lipoprotein (LDL), dan trigliserida. Aktifitas jasmani yang direkomendasikan adalah aktifitas jasmani intensitas sedang yang teratur 30 - 60 menit perhari, paling sedikit 4 hari dalam satu minggu atau minimal 150 menit/ minggu.

Diit yang dianjurkan adalah pembatasan kalori, peningkatan asupan serat, dan pembatasan karbohidrat. Khusus untuk penderita hipertensi diit yang disarankan adalah asupan garam yang dikurangi dan pembatasan alkohol.

Perubahan gaya hidup dalam kehidupan nyata sangat sulit dilakukan tanpa batituan dan pengawasan dari praktisi kesehatan profesional. Tolak ukur potensial untuk menentukan keberhasilan intervensi gaya hidup adalah penurunan $\mathrm{BB} 2 \mathrm{~kg}$ dalam 1 bulan atau $5 \%$ penurunan $\mathrm{BB}$ pada 6 bulan. $\mathrm{Hal}$ ini serupa dengan penurunan kadar glukosa plasma sebagai respon yang diinginkan dari intervensi gaya hidup. Tidak semua individu dengan risiko tinggi dapat menerima perubahan gaya hidup dan untuk mencapai ini diperlukan intervensi lain yaitu dengan obat.

\section{Intervensi Farmakologis}

Intervensi farmakologis untuk pencegahan DM biasanya direkomendasikan sebagai intervensi sekunder yang diberikan setelah atau bersama-sama dengan intervensi modifikasi gaya hidup. Jika dengan intervensi gaya hidup belum terjadi penurunan $\mathrm{BB}$ maka harus dipertimbangkan dimulainya penggunaan obat. (Soeatmadji $W$ Djoko dkke, 2009; Harrison T.R, 2008; Alberti K G M, ZImmet $P$ and Shaw J. 2007)

\section{Motformin}

Alasan penggunaan metformin sebagian besar berdasar pada catatan keamanan obat ini yang telah dipergunakan selama 40 tahun, namun demikian, metformin tidak direkomendasikan untuk semua orang dengan TGT. Metformin dapat menyebabkan acidosis laktat (gangguan iskemia pada ginjal dan hepar). Hasil DPP juga menyatakan bahwa metformin kurang betperan dalam pencegahan DM pada orang usia tua $>60$ tahun. Keterbatasan metformin juga disebabkan adanya efek samping saluran pencernaan yang bisa diatasi dengan peningkatan dosis secara bertahap.

\section{Acarbose}

Acarbose bekerja dengan cara menghalangi enzim yang mencerna karbohidrat. Pada studi STOP-NIDDM, dalam follow up 3,3 tahun acarbose menurunkan risiko DM sebesar $25 \%$ dan risiko penyakit kardiovaskular šcbesar $49 \%$. Adanya efek samping pada saluran pencernaan menimbulkan terjadinya drop out sebesar $31 \%$ (dibandingkan 19\% pada placebo) sehingga membatasi penggunaannya untuk pencegahan DM. Studi STOP-NIDDM merekomendasikan penggunaan acarbose pada orang yang bisa toleran dengan efek samping saluran pencernaan untuk pencegahan DM dan risiko kardiovaskular.

Pada beberapa pasien, acarbose mungkin dapat menurunkan BB. Hasil penelitian jangka panjang terhadap penderita TGT dan DMT2, membuktikan acatbose memberikan penurunan BB yang signifikan sebesar $0,7-0,9 \mathrm{~kg}$. pada penelitian STOP-NIDDM angka kejadian hipertensi yang baru terdiagnosis juga berkurang sebesar $34 \%$. Acarbose juga menurunkan kadar lipid terutama kadar lipid dan trigliserida saat puasa sebesar 15\%. Acarbose juga menurunkan aterogenisitas dari LDL, pada pasien dengan TGT.

\section{Orlistat}

Orlistat adalah sebuah obat yang bekerja dengan mekanisme menghalangi enzim yang memecah triglycerides di dalam saluran pencernaan. Hasil dati sebuah studi, menunjukkan orlistat dapat menurunkan BB sebesat $3-5 \mathrm{~kg}$ dalam 6 bulan, yang dapat dipertahankan dalam waktu 4 tahun. Pengobatan pada subjek TG'T yang obesitas dengan orlistat sebagai tambahan terhadap diit dan modifikasi gaya hidup dapat menurunkan risiko terjadinya DMT2. Hasil studi Xenical in the Pretention of Diabetes in Obese Subject (XENDOS), pada 3304 subjek obesitas yang tidak menyandang DM semua diberi petlakuan modifikasi gaya hidup yang intensif 
dan dibagi menjadi kelompok yang diberi orlistat atau placebo. Setelah 4 tahun, kelompok otlistat mengalami penurunan $\mathrm{BB}$ sebesar $6,9 \mathrm{~kg}$ sedangkan kelompok placebo $4,1 \mathrm{~kg}$. penurunan $\mathrm{BB}$ tersebut berhubungan dengan penurunan risiko DM sebanyak $37 \%$. Angka drop out yang tinggi (52\%) pada kelompok orlistat terkait dengan efek samping pada saluran pencernaan sehingga membatasi penggunaannya. (Soeatmadji W Djoko dkk, 2009; Harrison T.R, 2008; Alberti K G M, ZImmet $P$ and Sbav J. 2007)

\section{KESIMPULAN}

Penanganan dini dan pencegahan progresifitas DMT2 memberikan dampak yang sangat menguntungkan, yakni meningkatkan usia harapan hidup dan kualitas hidup.

Obsesitas khususnya obesitas abdominal merupakan pusat timbulnya DMT2 dan kelainan yang terkait. Dalam jangka waktu singkat, penutunan BB memperbaiki reisistensi insulin, hiperglikemia dislipidemia, serta menurunkan hipertansi. Targetnya adalah penurunan BB secara bertahap $(0,5-1,0 \mathrm{~kg} /$ minggu) dengan cara membatasi kalori dan meningkatkan aktifitas jasmani. Pemantauan BB dan lingkar perut harus dilakukan setiap hati/ minggu secara mandiri. Diit standar untuk menurunkan berat badan adalah dengan menurunkan asupan kalori 500-1000 kalori (tergantung gender dan usia) dari kebutuhan kalori, yang ditujukkan untuk mempertahankan BB.

Peningkatan aktifitas jasmani juga merupakan hal yang penting dalam mempertahankan penurunan BB. Aktifitas jasmani yang teratur memperbaiki resistensi insulin, menurunkan kadar insulin pada pasien dengan hiperinsilinemi, memperbaiki dislipidemia, dan menurunkan tekanan darah. Aktifitas jasmani meningkatkan aktifitas metabolisme jaringan otot serta meningkatkan kesehatan kardiovaskular secara umum. Peningkatan aktifitas fisik juga menurunkan tisiko DMT2.

IDF merekomendasikan bila intervensi gaya hidup saja sebelum cukup untuk mencapai penurunan BB yang diinginkan, dan/atau memperbaiki toleransi glukosa, maka pemberian metformin dosis $2 \times 250-850 \mathrm{mg} / \mathrm{sehari}$ (tergantung toleransi) layak dipertimbangkan dalam strategi pencegahan diabetes. Terapi farmakologis tersebut khususnya ditujukan bagi pasien yang berusia $<60$ tahun dengan BMI $>30 \mathrm{~kg} / \mathrm{m} 2$ (Indonesia $>25$ $\mathrm{kg} / \mathrm{m} 2$ ) dan GDP $>110 \mathrm{mg} / \mathrm{dl}$ serta tidak terdapat kontraindikasi. Pemberian acarbose dimulai dengan dosis $3 \times 50 \mathrm{mg} / \mathrm{hati}$ diminum saat makan dan dapat dinaikkan sampai $3 \times 100 \mathrm{mg} /$ hari.

$\mathrm{HbA} 1 \mathrm{c}$ dipandang perlu dimasukkan sebagai dalam pemeriksaan skrining dan diagnosis diabetes. Harga HbA1c relatif lebih mahal dibanding pemeriksaan glukosa puasa (plasma), akan tetapi secara keseluruhan efisiensinya jauh lebih baik jika digunakan sejak awal dalam skrining diabetes yang selanjutnya dapat memfasilitasi diagnosis dini serta dapat mengurangi beban biaya kesehatan terkait komplikasi diabetes.

HbAlc merupakan prediktor yang lebih kuat dalam menentukan resiko diabetes dan penyakit kardiovaskular dibanding glukosa puasa. Namun, data yang menunjukkan peran $\mathrm{HbAlc}$ sebagai alat skrining diabetes masih sangat terbatas dan bervatiasi, sehingga dipandang petlu sekali menetapkan cutoff standar untuk HbA1c. Dimasa mendatang HbA1c ini diperkirakan akan menjadi salah satu pemeriksaan untuk skrining maupun diagnosis diabetes. Dengan demikian, deteksi dini dan tindakan pencegahan yang efektif dapat dilakukan.

\section{DAFTAR PUSTAKA}

Ametican Diabetes Association. Standards of Medical Care in Diabetes - 2009. Diabetes Care 2009; 32.

Alberti K G M, ZImmet P and Shaw J. 2007. International Diabetes Federation : $A$ Consunsus on Type 2 Diabetes Prevention. Diabetic Medicine.

Gallagher Ej, Roith D, Blloomgarden Z., 2009. Revien of bemoglabin $A 1 c$ in the management of diabetes. Journal of Diabetes $19-17$.

Harrison T.R, 2008. : Principles of Internal Medicine, $17^{\text {th }}$ ed, McGraw-Hill Book Co Inc,

Little RR and Sacks DB. 2009. HbA1c: bou' do we measure it and what does it mean? Curr Opin Endocrinal Diabetes Obes; 16:113 - 118.

Saudek CD, Herman WH, Sacks DB, Bergenstal RM, Edelman D, Davidson MB., 2008. A New Look at Screening and Diagnosing Diabetes Mellitus. J Clin Endocrinol Metab 93 (7) : $2447-2453$.

Selvin E, Steffes MW, Zhu H, Matsushita K, Wagenknecht L, Pankow J, Coresh J, Brancati FL, 2010. Glycated Hemoglobin, Diabetes, and Cardionaschlar Risk in Nondiabetic Adults. N engl J Med ; 362:800 - 11 . 


\section{Vol. 7 No. 14 Januari 2011}

Soeatmadji W Djoko dkk, 2009. Panduan Pengelolaan dan Pencegahan Prediabetes, PB Persadia.

The Internal Expert Committee, 2009. International Expert Committee Report on the Role of the A1c Assay in the Diagnosis of Diabetes. Diabetes Care ; 32 : 1327-1334. 